\title{
HACIA UN NUEVO CONSENSO EN LA REGULACIÓN DE LOS CEMENTERIOS: LA EVOLUCIÓN DE LAS NORMAS CIVILES Y CANÓNICAS A LO LARGO DEL S. XX
}

\author{
TOWARDS A NEW CONSENSUS IN CEMETERY REGULATION: \\ THE CIVIL AND CANONICAL LAW EVOLUTION DURING THE \\ TWENTIETH CENTURY
}

\begin{abstract}
Andrés IrarráZaVAl Gomien*
RESUMEN: En la primera mitad del siglo XIX se crearon los cementerios en las afueras de las ciudades y se logró un consenso entre autoridades civiles y eclesiásticas sobre su regulación jurídica. La Ley Laica de Cementerios de 1883 rompió esta unidad, pero la evolución del derecho civil y canónico durante el siglo XX posibilitó una nueva convergencia. Actualmente los cementerios tienen una regulación que manifiesta el nuevo consenso alcanzado en el ámbito estatal y eclesiástico.
\end{abstract}

Palabras clave: Cementerios, cremación, relación Estado-Iglesia, Leyes Laicas, Derecho Canónico

\begin{abstract}
In the first half of the XIX century, cemeteries were created on cities' outskirts and a mutual understanding was achieved between civil and ecclesiastical authorities regarding their legal regulation. The 1883 Secularist Law of Cemeteries broke this consensus. However, civil and canon law developments during the twentieth century made possible a new convergence. Nowadays cemeteries have a regulation stating a new consensus reached between state and church..
\end{abstract}

Keywords: Cemeteries, cremation, relationship between state and church, Secular Laws, Canon Law

\section{INTRODUCCIÓN}

Si hace 130 años se hubiera realizado en Chile una encuesta sobre las cuestiones más debatidas entre la ciudadanía, una de las mencionadas sería la normativa sobre los cementerios. Esa respuesta hoy resultaría chocante, porque este tema no tiene connotación pública ni es debatido. Un hecho sencillo que ejemplifica esta realidad, es que las últimas modifi-

\footnotetext{
* Abogado. Licenciado en Ciencias Jurídicas y Sociales de la Universidad de Concepción. Profesor de las asignaturas de Historia del Derecho e Historia de las Instituciones de Chile en la Facultad de Derecho de la Universidad de los Andes, Chile. Dirección: Av. Mons. Álvaro del Portillo 12.455, Las Condes, Santiago. Correo electrónico: airarrazaval@miuandes.cl. El autor agradece la ayuda de los colaboradores José Manuel Bottinelli y Germán Guerrero.

Decreto del Ministerio de Salud No 69 de 2014. Introduce cambios menores en los números 69 y 70 de dicho Reglamento, que tratan de los crematorios.
} 
caciones realizadas al Reglamento General de Cementerios, el 17 de febrero de 2014, no fueron noticia ni tuvieron repercusión alguna en la prensa ${ }^{1}$.

En cambio, la promulgación en 1883 de una nueva ley de cementerios por el presidente Domingo Santa María ${ }^{2}$, estuvo acompañada de un intenso debate político y generó una reacción ciudadana que debió ser controlada por la fuerza pública. La polémica fue más allá de protestas y terminó involucrando a personas corrientes con un apasionamiento que hoy se consideraría desmesurado, dando lugar en palabras de Gonzalo Vial a una verdadera "guerra religiosa"3. Ricardo Krebs lo grafica señalando que "Ninguna otra medida causó en aquel tiempo tan profunda conmoción y tanto alboroto como la laicización de los cementerios. A los encendidos discursos en el Congreso y a las apasionadas polémicas en la prensa siguieron los actos de violencia: la exhumación de cadáveres en plena noche, la sepultación clandestina, la intervención de la fuerza pública. Los católicos se sintieron heridos en sus sentimientos más íntimos y se consideraron perseguidos por 'el liberalismo usurpador y tiránico' y el despotismo más atroz”.

La cuestión misma de los cementerios en el gobierno de Santa María ha sido tratada por numerosos especialistas ${ }^{5}$, pero se podría concluir que el consenso actual en torno a esta materia es fruto de la separación de los ámbitos espiritual y civil establecida en 1883 y consagrada definitivamente con la disociación jurídica del Estado y la Iglesia en 1925. Así lo parece insinuar por ejemplo Marco Antonio León, quien señala que la Constitución de Arturo Alessandri abre una nueva etapa de libertad para la Iglesia y el Estado, y que en ese contexto "cada uno de los poderes siguió su propio camino y los cementerios cayeron de lleno dentro del nuevo discurso estatal, frío, sanitario y legalista, confinando los espacios sagrados de la muerte a lo que son hoy en día: solo lugares de entierro"6.

Pero esto podría significar que la solución del conflicto fue el resultado de la reducción de las esferas jurídicas en juego a la sola normativa civil, excluyendo el componente canónico. Nos parece que esta postura implicaría simplificar una realidad más compleja, ya que las inhumaciones y ritos fúnebres comportan hasta nuestros días un aspecto religioso

\footnotetext{
1 Se revisaron las ediciones de los periódicos El Mercurio, La Tercera y La Segunda de los días 17, 18 y 19 de febrero de 2014 sin encontrar menciones al Decreto. Se buscaron referencias en el diario El Mercurio en otras fechas importantes sin resultado, en concreto en torno a la publicación del Decreto General de Cementerios de 1970 (ver nota 71) y su modificación del año 2003 que permite el entierro de creaturas que no alcanzaron a nacer y podría haber tenido más repercusión social (ver nota 75). Sí se halló una noticia al día siguiente de publicarse la Ley n ${ }^{\circ} 18.096$ de 1982 que transfiere la administración de los cementerios fiscales desde el Fondo Nacional de Salud a las municipalidades donde se ubican, en la que simplemente se describe este hecho y la situación del personal que se desempaña en los cementerios: EL MERCURIO (26/1/1982) p. C2.

2 LeY de 1883.

3 VIAL (2009) p. 835.

4 Krebs (1981) p. 33.

5 Se puede destacar "Sepultura sagrada, tumba profana. Los espacios de la muerte en Santiago. 1883-1932" de Marco Antonio León y “¿Qué hacer con Dios en la República? Política y secularización en Chile (1845-1885)” de Sol Serrano, que incluye un capítulo específico llamado "La muerte y el mercado: el pluralismo de los cementerios”. LeÓn (1997) y SERRANo (2009) capítulo VII, pp. 221 y ss.

6 LEÓN (1997) p. 64.
} 
en buena parte de la población ${ }^{7}$. Por tanto, debe existir una suerte de equilibrio entre los ámbitos jurídico y espiritual, estatal y eclesiástico, entre las regulaciones civil y canónica de los cementerios, que dé sustento a una realidad que los sigue involucrando por igual, aun en el contexto de un Estado separado jurídicamente de la Iglesia. Este nuevo consenso, que se manifiesta en la ausencia de polémicas sociales e intelectuales en torno a los cementerios desde la última década del siglo XIX, no ha sido mayormente explicado y puede ser objeto de un estudio más específico.

En esta línea, el presente artículo intenta encontrar las razones jurídicas que fundamentan esta nueva convergencia: cómo se vuelven a entrelazar los diferentes intereses que chocaron tan frontalmente hace poco más de un siglo, aunar a los actores que se enfrentaron públicamente -autoridades de Gobierno y eclesiásticas-, y generar un nuevo consenso social que continúa presente en la actualidad. Para lograr este objetivo, se debe estudiar la reglamentación de los cementerios y las relaciones entre el poder civil y la autoridad eclesiástica, teniendo presente que tanto el Estado como la Iglesia, junto con sus legislaciones propias -el derecho civil ${ }^{8}$ y el derecho canónico-, están en el origen del conflicto y son parte de la solución. Pero no basta con analizar la relación entre las normativas civil y eclesiástica en un momento concreto, sino que se requiere seguir su desarrollo en el tiempo: ambas legislaciones cambian en los 130 años transcurridos desde el conflicto y el análisis de su evolución -no de cada una de las dos instituciones o de sus derechos por separado, sino en conjunto- permitirá encontrar respuestas a la inquietud que da origen a esta investigación.

La metodología que se seguirá utiliza criterios cronológicos y temáticos: se describirán las normas civiles y canónicas que regulan en el tiempo a los cementerios, desde los inicios del siglo XIX hasta nuestros días, y se hará especial énfasis en su relación mutua de confrontación o complemento. Las fuentes a utilizar serán las regulaciones civiles y canónicas correspondientes, así como estudios relacionados con ambas, y la novedad estará principalmente en la relación que se buscará hacer entre ambos ámbitos, que habitualmente se analizan por separado.

\section{ANTECEDENTES CIVILES Y ECLESIÁSTICOS DE LA REGULACIÓN DE CEMENTERIOS HASTA MEDIADOS DEL SIGLO XIX}

Desde antiguo las inhumaciones han sido reguladas por leyes o costumbres debido a motivos culturales, religiosos o de higiene. En la cultura cristiano occidental la Iglesia Católica asumió la organización de los cementerios y les dio el carácter de lugar sagrado. Eran consagrados por los obispos con las ceremonias establecidas en el ritual romano de igual manera que se consagraban los lugares destinados al culto. Por esta razón las autoridades los

\footnotetext{
En un estudio reciente el mismo Marco Antonio León señala "Si bien se alude al proceso secularizador como una de las causas que han incidido en los cambios de la ritualidad religiosa del siglo XX, se tiende a omitir que la muerte sigue unida a creencias religiosas”. LEÓN (2017) p. 566.

8 Se menciona derecho civil en un sentido amplio, para contraponerlo al derecho canónico. Las normas del Estado en materia de cementerios son también de derecho administrativo, procesal, penal, etc. En el resto del artículo se usará "derecho civil" o "normas civiles" en este mismo sentido.
} 
consideraban parte integrantes de las iglesias parroquiales, les daban el estatuto de lugar de asilo y quedaban fuera del comercio?.

En la tradición española los antecedentes legales se remontan también a épocas pretéritas. La legislación visigótica contemplaba en el Liber Iudiciorum normas que regulaban las sepulturas, que fueron recogidas durante el siglo XIII en el Fuero Juzgo de Fernando III el Santo de Castilla ${ }^{10}$. Su hijo Alfonso X el Sabio también promulgó leyes sobre la materia en el Fuero Real ${ }^{11}$ y las Siete Partidas ${ }^{12}$. En la época medieval y hasta ya entrado el siglo XVIII la costumbre era enterrar a los difuntos católicos en las mismas iglesias, o si no en ermitas o claustros. También se construían cementerios junto a los templos. Esta tradición pasó a Chile durante el período indiano ${ }^{13}$, como lo muestran hasta hoy las lápidas existentes en la Iglesia Catedral de Santiago y otros templos construidos en la época colonial. Naturalmente estas sepulturas se encontraban dentro de los poblados, con la consiguiente preocupación de las autoridades locales por evitar que fueran focos de epidemias. En caso de enfermedades contagiosas, de las que resultaran numerosas víctimas, se enterraban los cadáveres fuera de las ciudades en lugares consagrados exprofeso para ellos ${ }^{14}$.

Para conocer las normas eclesiásticas referentes a los cementerios se debe tener presente que hasta inicios del siglo XX el derecho canónico no estaba codificado y se contenía en numerosas disposiciones de concilios y sumos pontífices recopiladas en el Corpus Iuris Canonici, cuya primera versión oficial, la Editio Romana, fue aprobada por el Papa Gregorio XIII en 1580 y rigió hasta la promulgación del Código de Derecho Canónico de 1917. El primer libro de esta compilación, el Decreto de Graciano, establecía los principios generales en la materia al señalar que las inhumaciones deberían hacerse en la parroquia donde el difunto tenía su domicilio y que no se podía elegir sepultura en otra parroquia arbitrariamente o sin motivos proporcionados ${ }^{15}$. Esta regulación inicial es complementada por normas posteriores que definen el pago de los derechos parroquiales y el modo de enterrar a las personas. Por ejemplo se establecen las condiciones para inhumar en conventos de religiosos y quién debe celebrar el funeral en este caso, cuándo se puede usar la sepultura de los mayores y el lugar de entierro de la mujer que casó varias veces ${ }^{16}$.

Durante el siglo XVIII el movimiento ilustrado promueve nuevos valores de orden, racionalidad, limpieza y salubridad que repercuten en el diseño y distribución del espacio urbano. En este contexto, y entre otras medidas para "sanear" las poblaciones, se hace

\footnotetext{
9 Fernández y García (1994) p. 55.

10 Por ejemplo, Fuero Juzgo, Libro XI, Tít. II, Leyes I y II. Sus titulados son: I. Los que facen danno en los monimentos de los muertos y II. Antigua. Si algun omne furta monumento de muerto. De San MarTín (1872) tomo I, p. 183.

11 Fuero Real, Libro IV, Tit. XVIII. De San Martín (1872) Tomo I, p. 419.

12 Siete Partidas, Primera Partida, Título XIII, Leyes IV y XI. La primera señala que los obispos son los encargados de señalar los cementerios, fijar su extensión y amojonarlos; la segunda trata de los enterramientos de ciertas dignidades en iglesias. De San Martín (1872) Tomo II, p. 222 (Ley IV) y 227 (Ley XI).

13 Barros (1991) p. 229.

14 Fernández y García (1994) p. 56.

15 Decreto de Graciano, II Parte, Causa XIII, Cuestión II.

16 Ruiz de Velasco (1907) pp. 56 a 63.
} 
necesario separar la ciudad de los vivos de la de los muertos. La historiadora Isabel Cruz explica cómo esta nueva concepción se abrió paso dificultosamente en la mentalidad de la época: "La lucha por establecer los cementerios fuera de las iglesias y núcleos urbanos había sido en Francia, a mediados del siglo XVIII, y luego en España, una característica querella ilustrada en que las ideas razonables de los progresistas enfrentaba las nociones y el sentir de una mayoría, anclada en creencias milenarias y en las prácticas de tradición cristiana y más cercanamente, barroca" ${ }^{17}$. En atención a estos motivos y fundándose en la necesidad de proteger la salubridad pública, Carlos III aprueba una Real Cédula el 3 de abril de $1787^{18}$ por la que establece la obligación de construir los cementerios fuera de las poblaciones, en sitios ventilados y distantes de las casas de los vecinos, aprovechando las ermitas existentes como capillas. Como esta medida no fue fácil de concretar, la Corona debió insistir en su aplicación en años posteriores.

La ordenanza de Carlos III no se alcanzó a aplicar en Chile antes de 1810, pero esta preocupación fue recogida por las autoridades en los inicios del proceso de Independencia. Los templos no daban abasto para más inhumaciones y las precarias condiciones de construcción de las iglesias multiplicaban los inconvenientes de usar estas edificaciones -en que se celebraban misas y actos litúrgicos con afluencia de público- para enterrar los cadáveres. Así, en 1811, el primer Congreso Nacional se plantea la necesidad de contar con lugares de entierro alejados de las ciudades ${ }^{19}$ y se inician las gestiones para financiar un cementerio público a las afueras de Santiago, las que serán interrumpidas por la guerra de Independencia.

Durante la administración de Bernardo O'Higgins (1817-1823) se retoman estas gestiones y en 1821 se inaugura el nuevo Panteón General en las cercanías del cerro Blanco, en la entrada norte de Santiago, hoy Cementerio General. En el intertanto, a fines de 1819, O’Higgins había acogido la petición de un grupo de ingleses anglicanos residentes en Valparaíso para comprar un terreno que les permitiera fundar un cementerio propio ${ }^{20}$. La inauguración de este recinto, llamado Cementerio de Disidentes, existente hasta el día de hoy en las laderas del cerro Panteón de Valparaíso, motivó que el Gobierno impulsara en

17 Cruz (2016) p. 220. Otras medidas promovidas por los gobiernos de la época fueron mejorar el orden y la circulación de las calles, crear áreas verdes y paseos peatonales, cuidar el abastecimiento de aguas y en general facilitar la higiene de la población. Esta concepción del espacio urbano se plasmó en un nuevo estilo arquitectónico y artístico, el neoclasicismo.

18 Novísima Recopilación de Leyes de España, Libro I De la Santa Iglesia, sus derechos, bienes y rentas, prelados y súbditos, Patronato Real, Tít. III De los cementerios de las Iglesias: entierro y funeral de los difuntos, Ley I Restablecimiento de la Disciplina en el uso y construcción de cementerios, según el ritual romano.

19 En la sesión del 18 de octubre de 1811, el Diputado por Puchacay Juan Pablo Fretes "leyó una proclama dirijida a manifestar la necesidad i ventajas de los establecimientos de cementerios públicos, la que se oyó con aplauso i se mandó copiar en los libros, i que circule a las provincias, pasándola, al efecto, al poder ejecutivo”. Sesión del Congreso NaCional (18/10/1811) p. 144.

20 La historiadora Lucrecia Enríquez destaca que "Bernardo O’Higgins apoyó el respeto a la libertad de conciencia de los disidentes, que eran fundamentalmente comerciantes extranjeros radicados en Valparaíso" (Enríquez (2013) p. 742). Hasta antes de la Independencia la presencia de no católicos en el país era muy excepcional. La emancipación posibilitó la llegada de extranjeros y con ellos algunos pertenecientes a diferentes confesiones protestantes, especialmente en Valparaíso. Escobar (2005) pp. 113-128. 
1821 la creación de un camposanto público en las afueras de la misma ciudad ${ }^{21}$ y apurara la terminación del Panteón General en Santiago. A estos primeros cementerios extramuros se sumaron otros en las periferias de las principales poblaciones del país, promovidos por el gobierno en 1823, que ordenó se construyesen panteones en todos los pueblos para que "se evite a ejemplo de la capital el abuso de sepultar cadáveres en los templos o dentro de las poblaciones"22.

Es importante destacar que la creación de cementerios alejados de las ciudades no fue vista como una medida laicista del Estado: lo importante era que el cadáver permaneciera en terreno sagrado, y esa aspiración se mantuvo viva con la consagración de los camposantos. En palabras de Sol Serrano: "El cementerio no obedecía a un intento de secularización de la muerte sino a la formación de un nuevo espacio sagrado ordenado y administrado por la autoridad civil”23.

Este consenso de las esferas civil y religiosa es refrendado por la normativa eclesiástica que se aplicaba en la época ${ }^{24}$. Mons. Justo Donoso describe en sus Instituciones de Derecho Canónico las exigencias básicas para los cementerios conforme a las prescripciones de los concilios: "conservarse bien cercados y seguros para preservarlos de las invasiones de los brutos, y para que no sirvan a usos profanos”25. Define la sepultura eclesiástica como la realizada en lugar sagrado conforme a los ritos y prescripciones de la Iglesia, y enumera las personas privadas de dicha sepultura. En su Manual del Párroco Americano señala que en Chile solo comenzó la costumbre de inhumar en estos lugares después de la independencia, sin darle mayor connotación a este hecho. A renglón seguido se centra en los aspectos que deben interesar a los sacerdotes: "Más importa al párroco saber á quiénes se prohíbe por los cánones ser enterrados en lugar sagrado, para que no se esponga á faltar a su deber, obrando contra las leyes de la Iglesia" ${ }^{\text {"6 }}$. Tras enumerar los diferentes casos -entre los que se encuentran los no católicos, los herejes, los que han fallecido en pecado mortal notorio y cierto- y las penas en que incurren los párrocos que no cuiden ello, se detiene en las normas que fijan el domicilio parroquial ${ }^{27}$. Prosigue señalando la importancia de cuidar los ritos funerarios como la celebración de la Misa praesente corpore, que se ha perdido con la

21 Barros (1991) p. 250.

22 DeCRETO de 1823.

23 Serrano (2009) p. 223.

24 Dadas las dificultades de precisar los cánones vigentes antes de la promulgación del primer Código de Derecho Canónico en 1917, se difundían hasta principios del siglo XX manuales que sistematizaban las materias y sus ámbitos de aplicación. Estos textos siguen siendo útiles en la actualidad para conocer las normas que se utilizaban en cada época y lugar. En el caso de Chile destacan las obras del obispo electo de Ancud Justo Donoso, "Instituciones de Derecho Canónico Americano" y el "Manual del Párroco Americano". El profesor Antonio Dougnac señala respecto a Donoso que sus Instituciones estuvieron "llamadas a darle fama imperecedera por el número de ediciones de que fue objeto y por su irradiación en toda la América Hispana”: DougnAC (2001) pp. 22-23. Lo mismo podría decirse del Manual del Párroco Americano, que fue editado en varias oportunidades.

25 Donoso (1852a) Tomo III, p. 99.

26 Donoso (1852b) p. 153.

27 Señala que con la proliferación de los cementerios extramuros han quedado sin efecto la mayor parte de las discusiones de los canonistas en torno a la elección de sepultura, pero que al seguir vigente el pago de los derechos correspondientes los párrocos deben conocer las normas que establecen quién tiene domicilio en la parroquia, deteniéndose en los casos más dudosos. Donoso (1852b) pp. 157 a 160. 
fundación de cementerios extramuros cuando no tienen una capilla y el cadáver es llevado directamente allí. También se detiene en algunos puntos concretos como el entierro de los pobres de solemnidad, el tiempo que debe transcurrir entre la muerte y el entierro, la costumbre de vestir el cadáver con los hábitos de alguna orden religiosa y los casos de exhumación ${ }^{28}$.

La conformidad de la Iglesia Católica a las inhumaciones en los nuevos cementerios extramuros también se refleja en la colaboración que hubo entre las autoridades civiles y religiosas para el funcionamiento de los camposantos: las primeras fijaban reglamentos en orden al cuidado de la salubridad pública y nombraba sus administradores y demás empleados subalternos, y la segunda otorgaba los pases -requisito indispensable- para proceder a la inhumación de los cadáveres. Pero, con el paso de los años, esta mutua asistencia se tensionó por la disminución de los derechos parroquiales que cobraban los sacerdotes al reducirse su papel en las ceremonias litúrgicas cuando el funeral no se celebraba en el templo. Estos aspectos administrativos y económicos afectaron paulatinamente la percepción de las autoridades públicas sobre los cementerios y, durante el gobierno de Manuel Bulnes, se promulgó una ley que establecía la facultad del Presidente de la República para fijar los aranceles que se debían cobrar en los cementerios, atribución que antes ejercían las autoridades eclesiásticas ${ }^{29}$. A esta disposición se agregó la dictación que hizo el Gobierno -amparándose en la ley- de un nuevo Reglamento para los Cementerios de Santiago, Valparaíso, Talca y Concepción, situación que se repitió en 1852 y en 1857 al promulgarse nuevas leyes de aranceles y dictarse reglamentos internos para otros cementerios del país ${ }^{30}$. Pero las bases de la regulación civil no fueron afectadas en el fondo y así lo reconoció expresamente el Código Civil que entró a regir el 1 de enero de 1857 y establecía que la organización de los cementerios se sujetaría a las normas canónicas ${ }^{31}$.

En alguna ocasión hubo diferencias de más envergadura entre las autoridades civiles y eclesiásticas, por ejemplo, cuando en 1855 el Gobierno acordó con representantes británicos destinar una zona aledaña al Cementerio General de Santiago para el entierro de disidentes, lo que a juicio de la Iglesia ponía en entredicho las exigencias canónicas para mantener su carácter sacro. Se tuvo que pactar como condición que el nuevo sector estuviera separado por un alto y grueso muro que manifestara claramente que se trataba de un terreno distinto del consagrado canónicamente para la inhumación de los fieles católicos ${ }^{32}$.

De todos modos, a pesar de los roces y dificultades recién descritos, se puede señalar que a mediados del siglo XIX se decantó la masificación de los cementerios fuera de las ciudades y se dejaron los entierros en los templos urbanos. Fue una solución aceptada por las autoridades políticas y por la Iglesia, en la que se complementaban sin contraposición

\footnotetext{
28 Donoso (1852b) pp. 161 a 167.

29 LEY de 1844.

30 Salas (1872) pp. 35-36.

31 Así lo establecía el artículo 586 del Código Civil al señalar que "Las cosas que han sido consagradas para el culto divino, se regirán por el derecho canónico". Entre estas "cosas" estaban los cementerios. Para más información ver SALINAS (2006).

32 Donoso (1946) pp. 244-245. El muro sigue en pie y puede visitarse en el Cementerio General, a la entrada del Patio de disidentes $\mathrm{N}^{\circ} 1$.
} 
los principales principios civiles y canónicos en juego: los terrenos fiscales destinados a la inhumación de cadáveres se consagraban conforme a las normas eclesiásticas. Y la creciente pluralidad religiosa, asentada especialmente en el puerto de Valparaíso, se solucionó con la creación de un cementerio para disidentes no consagrado canónicamente en esa ciudad al que siguió un segundo en Santiago, lo que permitió descomprimir una posible polémica entre católicos y no católicos, o entre las autoridades civiles y religiosas.

\section{TENSIÓN Y RUPTURA ENTRE LAS NORMATIVAS CIVIL Y CANÓNICA DURANTE LA SEGUNDA MITAD DEL S. XIX}

Fuera de Valparaíso -y a partir de 1855 también de Santiago- no se concretó la construcción de cementerios para no católicos, lo que significó que quienes tenían la posibilidad trasladaban a sus deudos al Cementerio de Disidentes dicha ciudad, o si no procedían a enterrarlos en lugares descampados, como las laderas del cerro Santa Lucía en Santiago. Esta situación, que naturalmente no era sustentable a largo plazo, no hizo crisis por las presiones de los credos protestantes ${ }^{33}$, sino de los mismos católicos. El fondo jurídico de este enfrentamiento radicará en la progresiva pérdida del equilibrio logrado entre las normas civiles y canónicas, y su consecuente repercusión entre las atribuciones gubernamentales y eclesiásticas.

A mediados del siglo XIX una parte de la intelectualidad y élite política del país se alejó paulatinamente de las tradiciones religiosas de sus antepasados en vistas a un mayor espíritu liberal, de corte anticlerical, que afectó especialmente las relaciones entre las autoridades eclesiásticas y civiles ${ }^{34}$. Así lo explica el historiador Zvonimir Martinic: "He aquí el verdadero problema de las diferencias entre la Iglesia y el Estado durante el siglo XIX; por un lado, a Iglesia veía con horror como la sociedad iba perdiendo, de manera cada vez más creciente, la relación con Dios, mientras que por el otro, el Estado, imbuido en la necesidad de desclericalizar a la sociedad para imponer en ella sus principios, veía a la Iglesia como su principal enemigo, sin ser capaz de objetivizar la realidad que se estaba viviendo entre ambas instituciones" 35

Se generaron situaciones que afectaban a los bautizados católicos que no se consideraban creyentes, provocando conflictos entre las autoridades eclesiásticas y el Gobierno. Este exigía que se tuviera con ellos el mismo trato que se tenía con los católicos practicantes y la Iglesia rehusaba equiparar ambas realidades. En el caso de los cementerios, consagrados y administrados conforme al derecho canónico, no se inhumaban a los bautizados

\footnotetext{
33 Se debe tener presente que su situación había mejorado notablemente en relación a los primeros años de la Independencia. Además de contar con un cementerio en Valparaíso y Santiago, en 1844 se había dictado una ley de matrimonio para disidentes y en 1865 una ley interpretativa del art. $5^{\circ}$ de la Constitución de 1833 que les permitía practicar su culto dentro del recinto de edificios de propiedad particular y la fundación de escuelas privadas para enseñar a sus hijos en sus propias doctrinas religiosas. VALENCIA (1986) p. 174. La aprobación de esta norma interpretativa fue objeto de un amplio debate, ver Estellé (1967) pp. 181-225.

34 Este distanciamiento no fue algo particular de Chile, sino que tiene sus antecedentes en el paso del Antiguo Régimen Absolutista al nuevo Liberalismo en la Europa de fines del s. XVIII y principios del XIX. VIAL (1981) pp. 29 y ss.

35 Martinic (2012) p. 76.
} 
que hubieran muerto sin querer recibir los últimos sacramentos de modo público, situación que comenzó a ser más frecuente durante la segunda mitad del siglo XIX ${ }^{36}$ y que gatilló una disputa que escaló hasta las más altas autoridades con ocasión del fallecimiento y entierro del Coronel Manuel Zañartu en Concepción en octubre de $1871^{37}$, ante la mirada sorprendida de una población mayoritariamente católica, pero al mismo tiempo respetuosa de la institucionalidad legal.

La solución para esta polémica vino a través del decreto del 21 de diciembre de 1871 del Presidente Federico Errázuriz Zañartu, ideado por los Ministros Eulogio Altamirano y Abdón Cifuentes, liberal el primero y conservador el segundo ${ }^{38}$. Era una solución de compromiso que establecía que los cementerios existentes contarían a partir de esa fecha con un sector no consagrado para permitir la inhumación de cualquier persona, independiente de sus creencias religiosas o su modo de vivirlas, al que se accedería por la misma puerta de entrada, y que los cementerios que a futuro se crearan con fondos públicos serían legos y exentos de jurisdicción eclesiástica. Esta liberalización fue aceptada por el Partido Conservador a cambio de la incorporación de un artículo que permitía la creación de cementerios privados, lo que posibilitaría contar con camposantos exclusivos para los católicos ${ }^{39}$. Al poco tiempo se comenzaban las obras del Cementerio Católico de Santiago, colindante con el General.

La Iglesia no miró con buenos ojos el acuerdo político alcanzado, ya que no solucionaba el conflicto jurídico que se producía entre la nueva normativa civil y lo estipulado por el derecho canónico, que impedía mantener la condición de terreno sagrado en los cementerios existentes. Este impedimento afectaría los restos de los miles de católicos allí enterrados y generaría gran incertidumbre entre sus deudos. Las autoridades eclesiásticas buscaron un arreglo especificando las características que debía tener la división entre ambos sectores de los cementerios, y evitando que la nueva área se extendiera sobre terrenos ya utilizados anteriormente por el cementerio, o en caso que así se hiciera se exhumaran los restos enterrados allí para trasladarlos al sector consagrado ${ }^{40}$.

La actitud de los obispos les acarreó la animadversión de los políticos liberales y la prensa del sector. Un ejemplo de ello fue la inscripción que el Intendente de Santiago Benjamín Vicuña Mackenna mandó instalar en el cerro Santa Lucía con ocasión de su remodelación y traslado de restos al nuevo sector habilitado en el Cementerio General: "A la memoria de los expatriados del cielo y de la tierra, que en este sitio, yacieron depositados durante medio siglo, 1820-1872. Setiembre de 1874. B.V.M.”41. El ambiente se crispó tras la ruptura de la Fusión Liberal-Conservadora ${ }^{42}$ y en 1877 se presentó un proyecto de secu-

\footnotetext{
36 SerRano (2009) pp. 231-235. Se mencionan varios conflictos entre las autoridades civiles y eclesiásticas por si correspondía enterrar a un difunto en lugar sagrado o no.

37 SALAS (1872) pp. 8 y ss.

38 En Abdón Cifuentes se conjugaban una visión práctica del derecho con una defensa férrea de la libertad de la Iglesia frente al poder temporal. Riquelme (1981) pp. 134 y 142.

39 VIAL (2009) pp. 861-862 (nota 164).

40 Serrano (2009) pp. 236-238.

41 ViCUÑa (1874) Lámina XLVI.

42 Encina y Castedo (1980) Tomo II, pp. 1293 y ss.
} 
larización total de los cementerios públicos, que entre debates y discordias fue aprobado en la Cámara de Diputados, pero que se estancó en el Senado tras la muerte del Arzobispo Rafael Valentín Valdivieso en 1878 -que dio lugar a un nuevo problema entre el Gobierno y la Iglesia por la sucesión- y el estallido de la Guerra del Pacífico en 1879.

La sucesión del Arzobispo Valdivieso se complicó por el régimen de Patronato establecido en la Constitución de 1833 y aceptado tácitamente por la Iglesia. Acorde a este, le correspondía presentar al Gobierno un candidato a la Santa Sede en caso de vacancia en un obispado, y en esta ocasión sugirió a un sacerdote de conocidas ideas liberales, Francisco de Paula Taforó, que fue rechazado por la jerarquía chilena que apoyaba la nominación del Vicario General de la Diócesis, Joaquín Larraín. El asunto quedó interrumpido por la Guerra del Pacífico, y tras su fin la nueva administración del Presidente Domingo Santa María volvió a insistir en el nombre de Taforó, lo que motivó que el Papa León XIII enviara un Delegado Pontificio, mons. Celestino del Frate, para estudiar la situación en terreno. Tras su recomendación negativa, el Santo Padre rechazó el nombre de Taforó y al comunicárselo del Frate a Santa María, este devolvió su pasaporte al Delegado y cortó relaciones diplomáticas con la Santa Sede ${ }^{43}$.

Tras el rompimiento de las relaciones con la Santa Sede, el Gobierno apuró y propició la aprobación del Proyecto de Cementerios Laicos presentado en 1877. Aunque no todos los parlamentarios del ala liberal lo apoyaron ${ }^{44}$, finalmente el antiguo proyecto fue aprobado y promulgado. Se publicó la nueva 'Ley de Cementerios' y entró en vigencia el día 2 de agosto de $1883^{45}$. Como señala Ricardo Krebs, "fue interpretada como señal de que el liberalismo ateo había declarado una verdadera guerra al catolicismo, guerra que, aparentemente, se libraba contra los muertos, pero que, de hecho, iba dirigida contra los vivos y que obedecía al propósito de exterminar el catolicismo en sus raíces” ${ }^{\text {" }}$.

Mons. Joaquín Larraín declaró el 6 de agosto execrados los cementerios fiscales y municipales, o sea, les quitó el carácter sagrado a sus terrenos y prohibió los actos de culto en sus capillas, siendo en la práctica una llamada a los fieles a trasladar los restos de sus seres queridos a cementerios católicos. La reacción del Presidente Santa María no se hizo esperar y antes de una semana, el 11 de agosto, derogaba la disposición del Decreto de 1871 que permitía la creación de cementerios particulares, imposibilitando a la Iglesia tener sus propios camposantos consagrados. Un triste ejemplo de las repercusiones de estas dos medidas fue que el recién terminado Cementerio Católico, que había sido bendecido en julio de 1883 y cuyo reglamento interno se actualizó el día 8 de agosto respetando las normas sanitarias en vigor, fue clausurado tres días después por el Intendente de Santiago ${ }^{47}$.

\footnotetext{
43 Krebs (2002) pp. 249-250

44 En el senado se enfrentó a la oposición del Radical José Francisco Vergara. Vial et al. (1995) pp. 90-91.

45 Ley de 1883. Constaba de un solo artículo: "En los cementerios sujetos a la administración del estado o de las Municipalidades, no podrá impedirse, por ningún motivo, la inhumación de los cadáveres de las personas que hayan adquirido o adquieran sepulturas particulares o de familia, ni la inhumación de los pobres de solemnidad".

46 KReBs (1981) p. 33.

47 Para una reseña de la Historia del Cementerio Católico de Santiago, ver León (1993) pp. 331 y ss.
} 
Estas semanas se vivió la conocida "guerra de cadáveres" en la que los católicos intentaban por todos los medios burlar la autoridad para enterrar a sus deudos en cementerios consagrados y estas para exhumar los restos y trasladarlos a los lugares públicos. Estos momentos fueron el clímax de la arrastrada tensión entre las autoridades civiles y eclesiásticas, entre la élite intelectual de carácter anticlerical y la católica, entre una disputa conceptual y la realidad de personas comunes que debían luchar por el entierro de sus deudos. Fue algo grotesco, que no podía durar mucho: "La situación era tan explosiva que más tarde se buscó un acuerdo por medio del cual el gobierno autorizó los cementerios particulares y la Iglesia levantó la execración accediendo a la bendición de la tumba”48.

A la Ley de Cementerios Laicos siguió algunos meses después la de Matrimonio Civil ${ }^{49}$ y finalmente la de Registro Civil en julio de $1884^{50}$. Que esta fuera la última de las tres en aprobarse, obligando a los párrocos en su calidad de funcionarios públicos a aplicar la nueva normativa civil mientras no existiera el Registro estatal, se vio como una burla vengativa a la Iglesia por parte del Gobierno del Presidente Santa María ${ }^{51}$. En paralelo se estudiaba en el Congreso un proyecto de reforma constitucional para terminar con la unión entre Estado e Iglesia, pero el Gobierno se opuso a esta propuesta ${ }^{52}$ y apoyó un proyecto de reforma parcial que no fue ratificado por el Congreso ${ }^{53}$.

Tras la promulgación de las famosas Leyes Laicas, con la consiguiente polémica por parte de una sociedad mayoritariamente católica que todavía no se reponía del rompimiento de relaciones diplomáticas con la Santa Sede, de un período de reajustes debido a la aplicación de las nuevas normas civiles y eclesiásticas, del rechazo del Presidente Santa María al proyecto de reforma constitucional que proponía la separación jurídica del Estado y la Iglesia, y de acercamientos entre las autoridades eclesiásticas y de gobierno, llegó por fin un período de calma. Esto permitió a la administración siguiente, liderada por el Presidente José Manuel Balmaceda, lograr un acuerdo con la Santa Sede para la designación de Mariano Casanova como nuevo obispo de Santiago en enero de $1887^{54}$. Se cerraba así la etapa más turbulenta que hasta entonces había vivido el régimen ya multisecular del Patronato en Chile, instaurado en el período indiano y continuado por las autoridades republicanas.

El derecho canónico posterior a la Ley Laica de Cementerios refleja la ruptura del antiguo consenso alcanzado en la primera mitad del siglo XIX de un modo muy sencillo: sus normas mantienen su aplicación solo a los cementerios consagrados omitiendo la nueva realidad civil. Así lo muestra por ejemplo la obra "Compendio de Derecho Canónico" del

\footnotetext{
48 Serrano (2009) p. 244.

49 LEY de 10/1/1884.

50 LEY de 17/7/1884.

51 IrarrázaVAl (2014) p. 329.

52 Domingo Santa María manifiesta claramente su opinión sobre este punto en su conocida carta autobiográfica de 8 de septiembre de 1885 a Pedro Pablo Figueroa, donde señala: “...La Iglesia no se ha separado del Estado, porque no he querido y he luchado por mantener la unión”. ENCINA y CASTEDo (1980) Tomo III, p. 1986.

53 SERrano (1981) pp. 175-178.

54 Vial (2009) Tomo 2, pp. 825-839.
} 
presbítero Crescente Errázuriz, editada en $1893^{55}$. Trata los cementerios con ocasión de los lugares sagrados refiriéndose solamente a los cementerios católicos y a la sepultura eclesiástica. Define los primeros como "los lugares benditos por autoridad del obispo, destinados a sepultar los cadáveres de los fieles muertos piadosamente" y explica que la segunda "consiste en dos cosas: en que el cadáver se entierre en lugar sagrado y en que el entierro se haga con las ceremonias y ritos prescritos por la Iglesia" ${ }^{56}$. Tras estos conceptos simplemente señala quiénes están privados de sepultura eclesiástica de acuerdo al derecho canónico.

\section{LA EVOLUCIÓN CANÓNICA Y CIVIL DE LAS NORMAS SOBRE CEMENTERIOS EN LA PRIMERA MITAD DEL SIGLO XX}

La dictación de las Leyes Laicas, al disociar las normativas civiles y eclesiásticas en materia de matrimonios, cementerios y registros, cerró una fuente histórica de roces entre el Estado y la Iglesia sin resolver el conflicto de fondo. La solución del Gobierno no fue buena para la Iglesia, ya que dejaba de complementar sus disposiciones en estas áreas con la vigencia del derecho canónico, lo que podía generar nuevos enfrentamientos. En cuanto a las inhumaciones, esta situación se prolongó durante las tres décadas siguientes, pero luego comenzó un proceso en que ambos cuerpos jurídicos volvieron a converger paulatinamente.

Debemos destacar, antes de analizarlo, que el nuevo consenso no se logró porque el Estado se volviera a sujetar en esta materia a la regulación canónica, o viceversa, porque la Iglesia modificara sus principios para someterse a las nuevas directrices civiles. La realidad fue que ambos sistemas jurídicos evolucionaron para integrar los cambios sociales de una época tan intensa como el paso del siglo XIX al XX. Esta transición se produjo en varios países que pasaron por procesos similares al chileno y en la misma Santa Sede, que cambió profundamente sus relaciones con el poder temporal tras la unificación de Italia y la pérdida de los Estados Pontificios ${ }^{57}$.

En el ámbito eclesiástico el gran cambio normativo se dio con la codificación del derecho canónico que reemplazó a la antigua compilación del Corpus Iuris Canonici. En 1917 el Papa Benedicto XV promulga el primer Código de Derecho Canónico que regirá hasta $1983^{58}$. La regulación de los cementerios esta normada en el título XII del nuevo código, sobre la Sepultura eclesiástica: mantiene las normas del Corpus Iuris sobre los cementerios y las inhumaciones incorporando una prohibición expresa a la práctica de la incineración de cadáveres. Establecía que: "Los cuerpos de los fieles difuntos deben ser sepultados, re-

\footnotetext{
55 Fidel Araneda dice respecto a esta obra que hecha "con claridad y orden y en forma breve, fue por mucho tiempo el único libro al cual tuvieron que echar mano profesores y alumnos”. Araneda (1946) p. 29. Crescente Errázuriz (1839-1931), presbítero desde 1863, profesor de Derecho Canónico en la Universidad de Chile entre 1873 y 1884, fue consagrado arzobispo de Santiago en enero de 1919.

56 Errázuriz (1893) p. 318. Es la misma descripción que realizaba Justo Donoso (ver Notas n. 25 a 29), con la diferencia que al ser esta obra posterior en 10 años a la ley de 1883 podría haberse referido a la existencia de los cementerios estatales y en cambio no los menciona.

57 El 20 de septiembre de 1870 los ejércitos del gobierno italiano ocuparon Roma y acabó el dominio temporal de los papas. Muchos autores coinciden en que la pérdida de los Estados Pontificios supuso a la larga un beneficio para el Papado. CÁrCel (1999) pp. 165-170.

58 Código de Derecho Canónico de 1917.
} 
probándose su cremación"59, y que "Los cadáveres de los fieles han de ser sepultados en el cementerio que, según los ritos prescritos en los libros litúrgicos aprobados, esté bendecido con bendición solemne o simple..." ${ }^{60}$. De acuerdo al Código un cementerio puede ser eclesiástico o civil conforme a la autoridad que lo ha erigido, sagrado o profano según si ha sido bendecido o no, y secular o religioso si está destinado a la inhumación de religiosos o de personas que no lo son ${ }^{61}$. A continuación trata de los cementerios eclesiásticos: "La Iglesia católica tiene derecho a poseer cementerios propios. Si, en alguna parte, es violado este derecho de la Iglesia y no hay esperanza de que se repare tal violación, cuiden los Ordinarios de los lugares de que los cementerios propios de la sociedad civil sean bendecidos si los que en ellos suelen ser enterrados son en su mayoría católicos, o, al menos, que en ellos tengan los católicos un espacio para ellos reservado y este bendecido. Si ni esto puede conseguirse, bendígase cada una de las tumbas cada vez, según los ritos prescritos en los libros litúrgicos aprobados"62.

La normativa canónica de 1917 coincide en dos materias con la legislación civil existente en Chile a principios del s. XX. Por una parte, en la generalización del uso del cementerio, ya que prohibía el entierro en iglesias salvo el caso de ciertas autoridades eclesiásticas como los obispos y abades ${ }^{63}$, y por otra, en el rechazo a la cremación, práctica que no se acostumbraba en Chile ${ }^{64}$. Pero, al mismo tiempo, mantiene diferencias de fondo que le llevan a privilegiar la creación de camposantos católicos por sobre el uso de los cementerios públicos.

De todos modos, aunque el nuevo Código no modificó mayormente la regulación canónica de los cementerios respecto a los años anteriores, sí actualizó su contenido a una época en que muchos países de raigambre cristiana contaban con normas civiles más plurales en el ámbito religioso. De esta manera, si bien el nuevo texto defiende el derecho de la Iglesia a contar con cementerios propios y bendecidos, establece también normas alternativas para los casos en que esto no sea posible. Así facilita la relación con los gobiernos civiles de países como Chile, dando a las autoridades eclesiásticas locales mayores posibilidades de actuar en esta materia sin radicalizar las posiciones.

En el ámbito civil nacional también se producen cambios normativos importantes. En 1918 se aprobó el primer Código Sanitario de Chile, cuyo Título IX denominado "De

59 Código de Derecho Canónico de 1917 , art. 1203, inc. $1^{\circ}$.

60 Código de Derecho Canónico de 1917, art. 1205, inc. $1^{\circ}$

61 ARTECHE (1946) p. 261

62 Código de Derecho Canónico de 1917, art. 1206, inc. 1, 2 y 3.

63 "No se sepulten en las iglesias los cadáveres, a no ser que se trate de los Obispos residenciales, de los Abades o Prelados Nullius, los cuales han de ser sepultados en la propia iglesia, o del romano Pontífice, de personas reales o de Cardenales de la S.I.R.”. Código de Derecho Canónico de 1917, art. 1205, inc. $2^{\circ}$.

64 El Código de Derecho Canónico de 1917 establecía además en el can. 1240, $₫ 1$. Son privados de sepultura eclesiástica, a no ser que antes de morir hubieran dado algunas señales de penitencia: $5^{\circ}$ Los que hayan dispuesto la cremación de su cadáver. $\mathrm{Ni}$ en los libros y artículos estudiados para preparar esta investigación se ha mencionado la cremación como una práctica frecuente en el s. XIX ni como tema de conflicto entre autoridades civiles y eclesiásticas. Asimismo, como se mencionará más adelante, el Código Sanitario de 1918 no hace referencia alguna a la cremación en el capítulo dedicado a la policía mortuoria, como sí lo hace el Código Sanitario de 1931. 
la Policía Mortuoria” actualiza la regulación de cementerios. Señala que debe haber al menos uno por cada comuna, da normas para el establecimiento de nuevos cementerios, las inhumaciones y exhumaciones, y expresa que se dictará un Reglamento para la ejecución de las disposiciones recogidas en este título ${ }^{65}$. A este Código le sigue uno nuevo en 1931, que en su Libro IV trata de la "Policía Mortuoria" y regula con más detalle que el anterior la materia, estableciendo también que "La inhumación, transporte y exhumación de cadáveres o restos humanos, así como la fundación, funcionamiento y clausura de cementerios, crematorios o establecimientos semejantes estarán regidos por las disposiciones de un reglamento especial" 66 .

En el intertanto, entre la dictación de ambos códigos sanitarios, sucede un hecho de especial relevancia, que influye indirectamente en el fondo de las dificultades que han provocado las disputas en torno a los cementerios desde la Independencia: en 1925 se promulga una nueva Constitución que terminó con el régimen de confesionalidad del Estado $^{67}$ y, por tanto, con la relación jurídica que unía a los sistemas normativos civil y canónico en materias comunes. La regulación sobre cementerios ya se había disociado con la Ley de 1883, pero esto era una excepción a la situación general que establecía la confesionalidad. Así se daba por ejemplo, que el Código Sanitario de 1918 contenía normas sobre el entierro de los obispos en las catedrales ${ }^{68}$, aspecto que ya no trata el Código de 1931.

Se decanta de esta manera un nuevo consenso en torno a la regulación civil y eclesiástica de los cementerios: la autoridad gubernamental regula los públicos y permite la creación de privados; las normas canónicas organizan los cementerios privados católicos y permite la bendición de las sepulturas para los casos en que no haya cementerio consagrado o el difunto no pueda ser inhumado en uno de ellos. Como señala la historiadora Sol Serrano, no solo estaba en juego la propiedad del terreno o la exclusividad religiosa de los camposantos, sino una manera de concebir socialmente la muerte: "También la muerte estaba cruzada por las nuevas definiciones de lo público y de lo privado. El argumento que trenza el relato es el afianzamiento de los derechos del individuo y la primacía del derecho de propiedad, Al final de esta historia, el catolicismo redefinió su concepto del espacio sagrado de la muerte como un espacio individual. El individuo se yergue como concepto jurídico y como actor sociológico en un contexto de crecimiento demográfico, de dramática urbanización y de la aparición de la mortalidad como un problema social que la ciencia de gobierno y la ciencia médica debían enfrentar" ${ }^{\prime 9}$.

\footnotetext{
${ }^{65}$ LEY n 3.385 de 1918, arts. 114-123. En el último artículo citado se establece la dictación del reglamento mencionado.

66 D.F.L. $\mathrm{N}^{\circ} 226$ de 1931, art. 227.

67 CEA (2008) p. 51.

68 LEY N 3.385 de 1918, art. 116.

69 Serrano (2009) p. 222. En la página 221 señala: "El cementerio como lugar de devoción a los muertos fue una gran innovación del siglo XIX. El paso de la bendición sagrada del terreno a la bendición de la fosa y más tarde al ataúd del individuo es la expresión más fuerte y material de la secularización del espacio público y de la reubicación de la esfera religiosa”.
} 


\section{ACTUAL REGULACIÓN DE LOS CEMENTERIOS Y LA CUESTIÓN DE LA CREMACIÓN}

Las normas contenidas en el Código de Derecho Canónico de 1917 y en el Código Sanitario de Chile de 1931 empalman con las normas eclesiásticas y civiles que están vigentes actualmente en materia de cementerios e inhumaciones. Las analizaremos con detalle para concluir si el nuevo consenso que se va decantando ya en la primera mitad del s. XX se fortalece o debilita en el último tiempo.

En el ámbito civil, la actual legislación de cementerios está contenida en el Libro VIII "De las inhumaciones, exhumaciones y traslado de cadáveres" del Código Sanitario ${ }^{70}$, que -conforme a lo estipulado por su artículo 136- se complementa con un "Reglamento General de Cementerios"71.

En el Código Sanitario están las normas generales referentes al tema. Se señala que solo en los cementerios legalmente autorizados se pueden inhumar cadáveres o restos humanos, que estos son autorizados por el Servicio Nacional de Salud, que en ellos no puede rechazarse la inhumación de un cadáver sin una justa causa calificada por el mismo Servicio, y que corresponde a las Municipalidades instalar cementerios en los lugares en que sean insuficientes ${ }^{72}$. También hace mención a las inhumaciones mismas: tiempo durante el que un cadáver puede permanecer insepulto, en quienes recae la obligación de dar sepultura a un difunto, la exigencia de contar con un certificado del médico que atendió al occiso o del Servicio Nacional de Salud para inscribir la defunción en el Registro Civil, y de la autorización que debe prestar el Director General de Salud para las exhumaciones y trasla$\operatorname{dos}^{73}$.

El Reglamento General de Cementerios fue publicado el 18 de junio de $1970^{74}$. Consta de 13 títulos y 85 artículos, más un artículo transitorio. Se refiere tanto a la organización de los cementerios, velatorios y crematorios, como a las sepulturas, cremaciones, exhumaciones, uso de cadáveres para fines científicos y sanciones ${ }^{75}$. Su último artículo señala que este Reglamento viene a derogar el antiguo Reglamento General de Cementerios, contenido en el decreto supremo 421, de 14 de abril de 1932, del Ministerio de Bienestar Social, y que sigue vigente el Reglamento de Cementerios Indígenas, aprobado por el decreto

\footnotetext{
70 D.F.L. No 725 de 1968.

71 "Un Reglamento contendrá las normas que regirán para la instalación y funcionamiento de los mencionados establecimientos y sobre la inhumación, cremación, transporte y exhumación de cadáveres”. D.F.L. N ${ }^{\circ} 725$ de 1968 , art. 136 , b.

72 D.F.L. $\mathrm{N}^{\circ} 725$ de 1968 , arts. 135 a 138.

73 D.F.L. $\mathrm{N}^{\circ} 725$ de 1968 , arts. 139 a 144.

74 Decreto del Ministerio de Salud No357 de 1970.

75 La denominación de los títulos es la siguiente: I. De las autorizaciones; II. De los cementerios; III. De las sepulturas; IV. De las sepultaciones; V. De los velatorios; VI. De las casas funerarias; VII. De los crematorios; VIII. De las exhumaciones y del transporte de cadáveres; IX. Distribución de cadáveres para fines de investigación científica; X. De la morgue y del depósito; XI. De los aranceles; XII. De las sanciones; Título final sobre vigencia y derogación de normas anteriores.
} 
supremo del Ministerio de Bienestar Social de 11 de noviembre de 1930 y modificado el 18 de diciembre del mismo año por un nuevo decreto supremo del mismo Ministerio ${ }^{76}$.

El Reglamento General de Cementerios no ha sufrido mayores modificaciones desde su entrada en vigencia. La principal fue introducida en 1982 por una ley que transfiere el dominio y la administración de los cementerios desde los Servicios de Salud a las Municipalidades ${ }^{77}$. Otros cambios menores han sido establecidos a través de decretos del Ministerio de Salud, que se refieren, entre otras materias, a la distancia que debe haber entre las casas funerarias y sus velatorios de los centros de atención médica, la reducción de cadáveres para ampliar la capacidad de los cementerios y su traslado dentro del territorio nacional, la enajenación de tumbas y la inhumación de criaturas que no han alcanzado a nacer ${ }^{78}$.

Lo mismo ha ocurrido con los artículos del Código Sanitario referentes a esta materia. Hasta la actualidad solo ha sufrido dos modificaciones menores, la primera en el artículo 139 por la Ley $\mathrm{N}^{\circ} 19.806$ del 31 de mayo de 2002 que establece que se puede retrasar la inhumación de un cadáver más de 48 horas si así lo requiere una investigación de carácter penal $^{79}$, y la segunda en su artículo 140 por la Ley $N^{\circ} 20.830$ del 21 de abril de 2015 que agrega al listado de personas que tienen la obligación de dar sepultura al cadáver a quien hubiera mantenido con ella un acuerdo de unión civil vigente al momento de la muerte ${ }^{80}$.

Estas normativas son recogidas por los reglamentos internos de los diferentes cementerios. Por ejemplo los pertenecientes a las cadenas "Parque del Recuerdo" ${ }^{81}$ y "Parques del

\footnotetext{
76 Decreto del Ministerio de Salud No 357 de 1970, art. 85, y Decretos del Ministerio de Bienestar SoCIAL N ${ }^{\circ} 1.754$ y 1.877 de 1930 .

77 LeY N 18.096 de 1982.

78 Decretos del Ministerio de Salud No 493 de 1976, que establece la obligación de realizar los trabajos en las sepulturas en tierra al año de adquirirse; No 350 de 1977, que para ampliar la capacidad de los cementerios permite la sepultación en los nichos temporales de largo plazo de los familiares, siempre que sus restos puedan ser reducidos; $\mathrm{N}^{\circ} 166$ de 1978, que permite recuperar parte del valor de una tumba si los restos se trasladan a otro cementerio; $N^{\circ} 319$ de 1980, que hace precisiones sobre la mantención de tumbas y mausoleos; $N^{\circ} 4$ de 1980, que prohíbe instalar casas funerarias en la misma cuadra de acceso a los servicios de salud; $\mathrm{N}^{\circ} 44$ de 1981, sobre enajenación de tumbas y permisos para sepultación en tumbas de familia; $N^{\circ} 455$ de 1982, sobre la distancia que debe haber entre los velatorios y los servicios de salud pública y privada; $\mathrm{N}^{\circ} 148$ de 1982, que permite que existan casas funerarias y velatorios en las cercanías del Servicio Médico Legal; N ${ }^{\circ} 240$ de 1983, que reglamenta la donación de órganos y modifica la situación de los cadáveres que no son reclamados en los centros asistenciales de salud; $N^{\circ} 470$ de 1987, sobre la distancia que debe haber entre el área de los cementerios destinada a la sepultación y las fuentes de agua para la bebida o el riego; $\mathrm{N}^{\circ} 205$ de 1989 , sobre requisitos que deben cumplir los velatorios; $N^{\circ} 509$ de 1991, que señala una excepción a los requisitos del decreto anterior; $N^{\circ} 254$ de 1992, sobre la entrega de cadáveres a universidades públicas o privadas para fines de docencia o investigación; $N^{\circ} 216$ de 2003, que impide rechazar la inhumación de una criatura no nacida si tiene certificado médico de defunción; $\mathrm{N}^{\circ} 54$ de 2004, que modifica norma sobre distancia que debe haber entre los velatorios y los establecimientos de atención médica; $N^{\circ} 4$ de 2006 sobre traslado de cadáveres dentro del territorio nacional; $N^{\circ} 69$ de 2014 con algunas precisiones sobre los servicios de cremación.

79 LEY $\mathrm{N}^{\circ} 19.806$ del 2002, art. 40. Es una precisión, ya que el artículo establecía esta posibilidad cuando se requería practicar una investigación científica o judicial.

${ }^{80}$ LEY No 20.830 del 2015, art. 38, i).

81 Reglamento Interno del Cementerio Parque del Recuerdo Américo Vespucio, art. 1.
} 
Sendero" "2 así como el "Parque Metropolitano de Santiago"83. El Cementerio Católico por su parte también las recoge, aunque haciendo a su vez referencia a las normas canónicas ${ }^{84}$.

Por su parte, el Código de Derecho Canónico de 1917 fue revisado en el pontificado de Juan Pablo II, quien promulga una nueva edición en 1983. En esta se simplifican las exequias eclesiásticas respecto a la normativa de 1917 "cuyo Derecho funerario era fruto de una evolución histórica que lo había ido complicando y, en ciertos aspectos, desvirtuando. El Código (de 1983) se limita a dar unas normas básicas, y las demás disposiciones necesarias para la celebración de exequias "con arreglo a Derecho" se dejan a las normas litúrgicas, es decir, al Ritual de Exequias elaborado según las directrices conciliares" ${ }^{85}$. Respecto a los cementerios el Código mantiene el espíritu de la legislación anterior: "Donde sea posible, la Iglesia debe tener cementerios propios, o al menos un espacio en los cementerios civiles bendecido debidamente, destinado a la sepultura de los fieles. Si esto no es posible, ha de bendecirse individualmente cada sepultura" ${ }^{\prime 6}$.

Respecto a los actos religiosos que se pueden realizar en los cementerios públicos o privados con ocasión de las exequias ${ }^{87}$, tanto el Código Sanitario como el Reglamento General de Cementerios no contienen prohibiciones al respecto. Este es un punto delicado, ya que su obstaculización podría ser un freno para que las personas creyentes optaran por su uso. Por el contrario, el Reglamento General de Cementerios menciona que entre los servicios que pueden prestar los cementerios están las capillas ${ }^{88}$, edificios destinados al culto que efectivamente existen en algunos cementerios, tanto públicos como privados ${ }^{89}$.

Por tanto, se puede concluir que las normas civiles y canónicas que reemplazan las establecidas en el Código Sanitario de 1931 y en el Código de Derecho Canónico de 1917 mantienen y fortalecen el consenso en materia de cementerios que se había logrado tras la separación jurídica del Estado y la Iglesia en 1925. Pero en el siglo XX surgió una nueva práctica que modifica sustancialmente la sepultura -la cremación- y que podría haber producido un nuevo quiebre de haber contrapuesto los ámbitos civil y eclesiástico.

Como antecedentes se puede señalar que durante las discusiones del siglo XIX referentes a los cementerios e inhumaciones no se trató de la cremación. Luego, dos normas casi paralelas, el Código de Derecho Canónico de 1917 y el Código Sanitario de Chile de 1918, no se contradicen al respecto: en el primero se prohíbe expresamente y en el segundo no se menciona. Posteriormente, el Código Sanitario de 1931 ya la incluye como posibilidad dentro de su articulado, pero sin imponerla como única alternativa, criterio que man-

\footnotetext{
82 Reglamentos Internos de los Cementerio Parque del Sendero, art. 1, inc. 1.

83 Cementerio Metropolitano. Reglamento Interno y de arreglos de Sepulturas y Nichos, art. 1.

84 Reglamento Interno del Cementerio Católico de Santiago, art. 1, inc. 1.

85 Cenalmor y Miras (2004) p. 485.

86 Código de Derecho Canónico de 1983, art. 1240, incs. 1 y 2.

87 Para más datos sobre la ritualidad mortuoria en el siglo XX se puede ver León (2017) pp. 565 y ss.

88 Decreto del Ministerio de Salud No 357 de 1970, art. 27, letra f).

89 Por ejemplo el Cementerio General de Santiago y el Cementerio Parque del Recuerdo Américo Vespucio tienen una capilla. En este último, su reglamento señala que la capilla se puede usar "para celebración de Servicios Religiosos de cualquier credo". Ver Reglamento Interno del Cementerio Parque del Recuerdo Américo Vespucio, art. 6, $\mathrm{n}^{\circ} 4$.
} 
tiene el Código Sanitario de 1968 actualmente vigente. Y, en los años que median entre los dos últimos códigos sanitarios, esto es entre 1931 y 1968, las normas canónicas cambian. En el año 1964 la Sagrada Congregación para la Doctrina de la Fe modificó la normativa sobre la cremación al señalar que en sí misma no contradice la fe católica. Este cambio fue recogido en el Código de Derecho Canónico de 1983: "El 1176 inc. 3 contiene la disciplina vigente sobre la cremación o incineración del cadáver de un fiel difunto: se aconseja vivamente la piadosa tradición de inhumarlo (sepultarlo), por responder mejor al simbolismo de la fe en la resurrección; pero no se prohíbe la cremación, con tal que no se elija por razones contrarias a la fe (c. 1184 , inc. $\left.1,2^{\circ}\right) \ldots$ El vigente Ritual de exequias prevé que los ritos que suelen celebrarse en la capilla del cementerio puedan tener lugar en el edificio de la cremación" ${ }^{\prime 0}$.

Al hacer un análisis de las normas en juego se desprende que en ningún momento las normas civiles y canónicas que regulan la cremación se contrapusieron de modo excluyente, y, que por tanto, no llegó a producirse un quiebre que pudiera haber puesto en peligro el consenso alcanzado en la regulación de los cementerios. Aún más, recientemente, la Congregación para la Doctrina de la Fe emitió una instrucción en la que vuelve a recomendar la sepultura de los difuntos en los cementerios u otros lugares sagrados, especificando que para el caso de la cremación las cenizas "por regla general, deben mantenerse en un lugar sagrado, es decir, en el cementerio o, si es el caso, en una iglesia o en un área especialmente dedicada a tal fin por la autoridad eclesiástica competente" ${ }^{91}$. Esta nueva orientación tampoco se contrapone a las normas civiles en la materia, que no obligan a la dispersión de las cenizas.

\section{CONCLUSIONES}

Como ya se ha descrito, durante el siglo XIX el Estado y la Iglesia modifican sus normas mortuorias buscando la generalización del cementerio extramuros, solución más eficaz de cara a las necesidades demográficas y avances en materias de salubridad pública. Aunque los cambios civiles y canónicos no fueron del todo paralelos y dieron lugar a conflictos entre ambas esferas de poder, se llegó a una situación de equilibrio hacia mediados de siglo. Pero esta armonía duró poco, ya que con la irrupción del liberalismo anticlerical la situación volvió a tensarse por motivos religiosos en las décadas siguientes. La dictación de la Ley Laica de Cementerios de 2 de agosto de 1883 marcó el culmen de estas controversias en torno a las inhumaciones, al disociar las normativas civiles y canónicas.

Tras su promulgación hubo un breve período de confrontación entre el Estado y la Iglesia y luego ambos poderes acercaron posiciones, llegándose a una nueva situación de equilibrio jurídico, en la que se permite la existencia de cementerios católicos y se pueden

90 Cenalmor y Miras (2004) pp. 485-486. En la misma cita se explica: "El CIC 1917 prohibía la cremación y negaba la sepultura eclesiástica a los fieles que la eligieran, por la frecuente vinculación de esa práctica con motivos contrarios a la religión. Según la norma vigente, es lícito optar por la cremación sin necesidad de que concurra ninguna causal especial. Ya en 1964 la S. Cong. Para la Doctrina de la Fe, en la Instr. Piam et constantem consideraba que la cremación, en sí misma, no implica nada contrario a la fe y, en consecuencia, la permitía”.

91 InSTRUCCIÓN de 2016, n. 5. 
bendecir individualmente las tumbas en los cementerios que no lo son. Esta solución significó una cesión momentánea de ambas instituciones - permitir los cementerios particulares por parte del Gobierno y no insistir en la desacralización completa de las necrópolis de administración fiscal- que se perpetuó en el tiempo y fue confirmada por la evolución posterior de los sistemas jurídicos civil y canónico.

La interrogante sobre las razones para explicar el actual consenso en la regulación de los cementerios, con la que se introducía este artículo, podría ser respondida al menos de dos maneras a la luz de los antecedentes estudiados.

En primer lugar, señalando que la confrontación que hubo, especialmente a fines del s. XIX, se debió a las importantes diferencias que se produjeron entre la legislación civil y canónica de cementerios. Actualmente, al no existir entre ambos sistemas jurídicos normas contradictorias relevantes, no hay motivos que produzcan polémicas a nivel de autoridades ni en el sentir popular.

La segunda forma, es decir que los cambios que afectaron durante estos últimos 130 años a los cementerios han influido en el derecho -tanto civil como canónico- que los regula. Los avances en salubridad pública y en el control de enfermedades contagiosas; las mejoras en las técnicas de construcción de los nichos y mausoleos; la mayor pluralidad religiosa, que ha sido reconocida por el Estado y la libertad religiosa que ha sido defendida con fuerza en las enseñanzas la Iglesia Católica desde la segunda mitad del siglo $\mathrm{XX}^{92}$; la sensibilidad respecto a la muerte que continúa existiendo en la población, como lo demuestra la experiencia cotidiana, etc., han sido recogidos por los legisladores y autoridades eclesiásticas. Estos nuevos datos y experiencias han perfeccionado las normativas, y al conocerse mejor una realidad que tiene componentes materiales y espirituales se han acercado las posiciones jurídicas civiles y eclesiásticas. Más aún, se podría señalar que con estos avances las posibles contradicciones entre ambas visiones tienden a desaparecer: el Estado -que mantiene un carácter neutro frente a las creencias que no atentan contra el bien común- no tiene por qué poner trabas a alternativas razonables que manifiesten la legítima libertad de sus ciudadanos, y la Iglesia Católica puede dar orientaciones a sus fieles que al estar dirigidas al bien común no los separan de las personas que no comparten su $\mathrm{fe}^{93}$.

De todas maneras, cabría preguntarse si una materia de esta naturaleza -al no existir una relación jurídica entre el Estado y la Iglesia desde la separación de ambas instituciones en 1925- puede dar lugar actualmente a una polémica semejante a la de los cementerios en 1883. A primera vista la respuesta sería no, porque una confrontación entre normas civiles y canónicas no debiera tener mayor efecto al no existir la antigua relación jurídica de Patronato. Pero, por otra parte, al tratarse de un país de mayoría católica, si la contraposición toca algún punto de la doctrina o piedad popular sí podría generarse un conflicto de carácter religioso como lo fue el de fines del siglo XIX.

92 Ver Declaración Dignitates Humanae, 7 de diciembre de 1965, n. 15, y Martínez (2003) p. 67.

93 Esta segunda conclusión podría dar luces para estudiar otras realidades donde las creencias cristianas chocan con las aparentes aspiraciones de una sociedad moderna, como pueden ser las referentes a la dignidad del no nacido, el valor del matrimonio para toda la vida entre un hombre y una mujer, la libertad en la educación de los hijos, etc. El futuro desarrollo de la genética o de la psicología seguramente darán luces para superar las contradicciones que actualmente vemos en algunas de estas materias. 
Una materia similar a los cementerios que podría servir para ejemplificar lo señalado es la cremación, en el sentido que el Gobierno la impusiera obligatoriamente por razones de espacio o salubridad pública y las normas canónicas la prohibieran. Como se ha explicado, hasta ahora en ningún momento ha existido una oposición de las normas civiles y canónicas en este tema. Al contrario, el desarrollo de armónico de ambos cuerpos legales ha posibilitado que se puedan construir criptas para conservar las cenizas en parroquias y templos, reabriendo la alternativa de enterrarse en lugares destinados al culto que se había cerrado a inicios del s. XIX con la creación de los cementerios extramuros.

Las menciones de los últimos párrafos a la Iglesia Católica se pueden hacer extensivas actualmente a las confesiones religiosas conforme a la Ley de entidades religiosas ${ }^{94}$. Como señala el profesor Carlos Salinas, esta ley "junto con establecer el procedimiento que permite a las confesiones religiosas diversas de la Iglesia católica y de la Iglesia ortodoxa del patriarcado de Antioquía alcanzar personalidad jurídica de derecho público, ha venido a regular, por primera vez en el ordenamiento jurídico chileno, los contenidos mínimos del derecho de libertad religiosa consagrado en las constituciones de 1925 y 1980 a las personas y confesiones religiosas".

Se puede señalar, a modo de conclusión final, que aunque actualmente no haya una relación jurídica formal entre el Estado y la Iglesia, esto no significa que el ámbito canónico esté suprimido de la sociedad y por tanto de la esfera jurídica civil: sigue siendo importante que exista una correlación entre las normas civiles y canónicas en materias que afectan temas de interés general.

\section{BIBLIOGRAFÍA CITADA}

Araneda, Fidel (1946): Hombres de relieve de la Iglesia Chilena (Santiago, Editorial Difusión Chilena).

Arteche, Gonzalo (1946): El Código de Derecho Canónico traducido y comentado, tomo II (Padre Las Casas, Chile, Imprenta San Francisco).

Barros, Diego (1911): Obras Completas, Tomo X, Estudios Histórico-Bibliográficos, cap. VII, El entierro de los muertos en la época colonial (Santiago, Imprenta Cervantes).

CAmpos, Fernando (1999): Historia Constitucional de Chile (Santiago, Editorial Jurídica, 7a edición).

CÁrCel, Vicente (1999): Historia de la Iglesia, Tomo III La Iglesia en la época contemporánea (Madrid, España, Ediciones Palabra).

Cea, José Luis (2008) Derecho Constitucional Chileno, Tomo I (Santiago, Ediciones Universidad Católica, $2^{\text {a }}$ edición actualizada).

Cennalmor, Daniel, y Miras, Jorge (2004): El Derecho de la Iglesia. Curso básico de Derecho Canónico. Colección de textos teológico-pastorales CELAM (Navarra, España, Ediciones Universidad de Navarra, Primera edición para Latinoamérica).

94 LEY N 19.638 del 1999. 
Correa, Sofía (1981) "El partido conservador ante las Leyes Laicas 1881-1884" en KreBS, Ricardo (edit.), Catolicismo y laicismo. Seis estudios (Santiago, Ediciones Nueva Universidad) pp. 75-118.

Cruz, Isabel (2016): Patrimonio Artístico de Chile. De la Independencia a la República. 1790-1840 (Santiago, Origo Ediciones).

De San Martín, Antonio (1872): Los Códigos españoles concordados y anotados, tomos I y II ( $2^{a}$ edición, Editor Antonio de San Martín, Madrid).

Donoso, Justo (1852): Instituciones de Derecho Canónico Americano, Tomo III (París, Francia, Librería de Rosa, Bouret y Cía.).

Donoso, Justo (1852): Manual del párroco americano (París, Francia, Librería de Rosa, Bouret y Cía.).

Donoso, Ricardo (1946): Las ideas políticas de Chile (Ciudad de México, México, Fondo de Cultura económica).

DougnaC, Antonio (2013-2014): "La producción canonista italiana en dos pensadores hispanoamericanos de comienzos del siglo XIX: el chileno Justo Donoso y el peruano Francisco de Paula González Vigil”, Revista Chilena de Historia del Derecho, No 24: pp. 15-189.

El Mercurio (26/01/1982) p. C2.

Encina, Francisco A., y Castedo, Leopoldo (1980): Resumen de la Historia de Chile, Tomos II y III (Santiago, Editorial Zig-Zag, 13a edición).

EnRíQueZ, Lucrecia (2013): "Un proyecto de Iglesia Nacional”, en Silva, Fernando (edit.), Historia de la república de Chile, vol. I. 1808-1826, Camino a la Independencia (Santiago, Zig-Zag) pp. 711-756.

Errázuriz, Crescente (1893): Compendio de Derecho Canónico (Santiago, Imprenta Barcelona, 2a edición).

Escobar, Juan (2005): "Protestantes en Valparaíso: Análisis ecuménico", en Concha, María Inés, Salinas, Carlos y Vergara, Francisco (edit.), Actas del Primer Simposio de Historia Religiosa de Valparaíso (Valparaíso, Ediciones Universitarias de Valparaíso) pp. 113-128.

Estellé, Patricio (1967): "El debate de 1865 sobre la libertad de cultos y conciencia”, Estudios de Historia de las Instituciones politicas y sociales, n. 2: pp. 181-225.

Fernández, María del Carmen, y García, Mariano (1994): "Los cementerios. Competencias municipales y producción documental", Boletín de la Confederación de Asociaciones de Archiveros, Bibliotecarios, Museólogos y Documentalistas, Tomo 44, № 3: pp. 55 a 85. Disponible en http://dialnet.unirioja.es/servlet/articulo?codigo=50914. Fecha de consulta: 27 de mayo de 2017.

Irarrázaval, Andrés (2014): "Los inicios del Registro Civil en Chile, ¿̇ruptura o continuidad con las antiguas partidas eclesiásticas?", Revista de Estudios Histórico-Jurídicos, n. XXXVI: pp. 315-341.

Krebs, Ricardo (1981) "El pensamiento de la Iglesia frente a la laicización del Estado en Chile 1875-1885” en Krebs, Ricardo (edit), Catolicismo y laicismo. Seis estudios (Santiago, Ediciones Nueva Universidad) pp. 7-74. 
IrarrázAVAL Gomien, Andrés Hacia un nuevo consenso en la regulación de los cementerios...

Krebs, Ricardo (2002): La Iglesia de América Latina en el s. XIX (Santiago, Ediciones Universidad Católica de Chile).

LeÓn, Marco Antonio (1993): "De Capilla a la fosa común: el cementerio católico parroquial de Santiago, 1878-1932”, Historia, vol. 27: pp. 331-375.

LEÓn, Marco Antonio (1997): Sepultura sagrada, tumba profana. Los espacios de la muerte en Santiago, 1883-1932 (Santiago, Colección Sociedad y Cultura, DIBAM, LOM Ediciones).

LeÓN, Marco Antonio (2017): "Universalidad y singularidad en el "último adiós": las redefiniciones de la ritualidad mortuoria en el Chile contemporáneo (1930-2010), en SÁnchez, Marcial (director), Historia de la Iglesia en Chile, Tomo V (Santiago, Editorial Universitaria) pp. 563-639.

Martínez, José A. (2003) Encíclicas de Juan Pablo II (Madrid, España, Edibesa, 5a edición).

Martinic, Zvonimir (2012): Las manifestaciones de la pugna Iglesia-Estado en Chile respecto de la sucesión arzobispal de Santiago. 1878-1886 (Tesis doctoral para optar al grado en Historia, Universidad de Chile, Santiago). Disponible en internet: http://repositorio. uchile.cl/bitstream/handle/2250/113780/Martinic\%20Zvonimir.pdf?sequence=1. Fecha de consulta: 27 de mayo de 2017.

Riquelme, Alfredo (1981) "Abdón Cifuentes frente a la laicización de la sociedad. Las bases ideológicas” en Krebs, Ricardo (edit), Catolicismo y laicismo. Seis estudios (Santiago, Ediciones Nueva Universidad) pp. 119-151.

Ruiz de Velasco, Francisco (1907): Defensa de los Cementerios católicos contra la secularización y reivindicación de los derechos parroquiales en el entierro y funerales (Madrid, España, Baena Hermanos Impresores).

Salas, José Hipólito (1872): Los cementerios. Por el Obispo de la Concepción (Valparaíso, Imprenta del Mercurio, de Tornero y Letelier, 2a edición). Visible en http://www.memoriachilena.cl/602/w3-article-9238.html. Fecha de consulta: 27 de mayo de 2017.

Salinas, Carlos (2006): El influjo del derecho Canónico en el Código Civil de la República de Chile (Valparaíso, Ediciones Universitarias de Valparaíso).

Salinas, Carlos (2009): "El derecho eclesiástico del Estado de Chile al tiempo del Bicentenario: logros y dificultades", Revista de Derecho de la Pontificia Universidad Católica de Valparaiso, n. XXXIII, $2^{\circ}$ semestre: pp. 499-533.

Serrano, Sol (1981) "Fundamentos liberales de la separación del Estado y la Iglesia 18811884 ” en KReBs, Ricardo (edit), Catolicismo y laicismo. Seis estudios (Santiago, Ediciones Nueva Universidad) pp. 153-209.

Serrano, Sol (2009): ¿Qué hacer con Dios en la República? Política y secularización en Chile (1845-1885) (Santiago, Fondo de Cultura Económica, Segunda reimpresión)

Sesión del Congreso Nacional (18/10/1811), visible en http://www.memoriachilena.cl/ archivos2/pdfs/mc0027501.pdf, p. 42. Fecha de consulta: 17 de junio de 2017.

Valencia, Luis (1986): Anales de la República (Santiago, Editorial Andrés Bello, 2a edición).

VIaL, Gonzalo (1981): Historia de Chile (1891-1973), Volumen I, Tomo I, Primera parte "La ruptura del consenso doctrinario" (Santiago, Editorial Santillana). 
Vial, Gonzalo, Valderrama, Pablo y Vásquez, David (1995): Historia del Senado de Chile (Santiago, Editorial Andrés Bello).

Vial, Gonzalo (2009): Chile. Cinco siglos de Historia, tomo 2 (Santiago, Editorial Zig-Zag). Vicuña, Benjamín (1874): Álbum del Santa Lucía dedicado a la Municipalidad de Santiago (Santiago, Imprenta de la Librería del Mercurio).

\section{NORMAS CITADAS}

Código Civil de Chile (14/12/1855).

Código de Derecho Canónico (1917).

Código de Derecho Canónico (1983).

Declaración Dignitates Humanae, Concilio Vaticano II (7/12/1965).

Decreto del Departamento de Gobierno y Relaciones Exteriores (3/6/1823), sobre Erección de panteones en los pueblos, en Boletín de las Leyes y de las Ordenes y Decretos del Gobierno, reimpresión oficial, tomo I, Valparaíso, 1845, libro I, n. 16 p. 112.

Decreto de Graciano, II Parte, Causa XIII, Cuestión II

Decreto del Ministerio de Salud Nº 357 (18/6/1970), aprueba Reglamento General de Cementerios.

Decreto del Ministerio de Salud No 493 (3/3/1976), aprueba modificación del Decreto No357 de 1970.

Decreto del Ministerio de Salud No 350 (21/1/1977), aprueba modificación del Decreto $\mathrm{N}^{\circ} 357$ de 1970.

Decreto del Ministerio de Salud Nº 166 (22/8/1978), aprueba modificación del Decreto $\mathrm{N}^{\circ} 357$ de 1970.

Decreto del Ministerio de Salud Nº 319 (14/1/1980), aprueba modificación del Decreto $\mathrm{N}^{\circ} 357$ de 1970.

Decreto del Ministerio de Salud No 4 (5/2/1980), aprueba modificación del Decreto N$^{\circ}$ 357 de 1970.

Decreto del Ministerio de Salud Nº 44 (19/3/1981), aprueba modificación del Decreto No357 de 1970.

Decreto del Ministerio de Salud No 455 (3/6/1982), aprueba modificación del Decreto $\mathrm{N}^{\circ} 357$ de 1970.

Decreto del Ministerio de Salud No 148 (23/8/1982), aprueba modificación del Decreto $\mathrm{N}^{\circ} 357$ de 1970.

Decreto del Ministerio de Salud No 240 (3/12/1983), Reglamento del Libro Noveno del Código Sanitario.

Decreto del Ministerio de Salud No 470 (28/9/1987), aprueba modificación del Decreto $\mathrm{N}^{\circ} 357$ de 1970.

Decreto del Ministerio de Salud No 205 (11/1/1989), aprueba modificación del Decreto $\mathrm{N}^{\circ} 357$ de 1970.

Decreto del Ministerio de Salud No 509 (9/1/1991), aprueba modificación del Decreto $\mathrm{N}^{\circ} 357$ de 1970.

Decreto del Ministerio de Salud No 254 (7/11/1992), aprueba modificación del Decreto $\mathrm{N}^{\circ} 357$ de 1970 y del Reglamento del Libro Noveno del Código Sanitario. 
IrARRÁZAVAL GOMIEN, Andrés Hacia un nuevo consenso en la regulación de los cementerios...

Decreto del Ministerio de Salud No 216 (17/12/2003), aprueba modificación del Decreto $\mathrm{N}^{\circ} 357$ de 1970 y $\mathrm{N}^{\circ} 161$ de 1982.

Decreto del Ministerio de Salud No 54 (19/5/2004), aprueba modificación del Decreto No357 de 1970.

Decreto del Ministerio de Salud No 4 (8/2/2006), aprueba modificación del Decreto Nº 357 de 1970.

Decreto del Ministerio de Salud Nº 69 (17/2/2014), aprueba modificación del Decreto No357 de 1970.

Decreto del Ministerio de Bienestar Social No 1.754 (11/11/1930), Reglamento de Cementerios Indígenas.

Decreto del Ministerio de Bienestar Social Nº 1.877 (18/12/1930), aprueba modificación del Decreto $\mathrm{N}^{\circ} 1.754$ de 1930.

D.F.L. N² 226 (29/5/1931), Código Sanitario

D.F.L. N $\mathrm{N}^{\circ} 25$ (31/1/1968), Código Sanitario de Chile.

Fuero Juzgo, de Fernando III de Castilla.

Fuero Real, de Alfonso X de Castilla.

Instrucción Ad Resurgendum CUM Christo de la Congregación para la Doctrina de la FE (15/8/2016), acerca de la sepultura de los difuntos y la conservación de las cenizas en caso de cremación.

Ley (10/1/1844), de Cementerio Públicos.

LeY (2/8/1883), de Cementerios Laicos.

LEy (10/1/1884), de Matrimonio Civil.

LeY (17/7/1884), de Registro Civil.

Ley N 3.385 (22/6/1918), Código Sanitario.

LEY $N^{\circ} 18.096(25 / 1 / 1982)$, que transfiere a las municipalidades los cementerios que indica y les encomienda su gestión.

LEY $\mathrm{N}^{\circ} 19.638$ (14/10/1999), de entidades religiosas.

LEY $N^{\circ} 19.806$ (31/5/2002), de normas adecuatorias del sistema legal chileno a la reforma procesal penal.

LeY N 20.830 (21/4/2015), que crea el acuerdo de unión civil.

Novísima Recopilación de Leyes de España, Libro I De la Santa Iglesia, sus derechos, bienes y rentas, prelados y súbditos, Patronato Real, Tít. III De los cementerios de las Iglesias: entierro y funeral de los difuntos, ley I Restablecimiento de la Disciplina en el uso y construcción de cementerios, según el ritual romano.

Reglamento Interno del Cementerio Católico de Santiago, disponible en http://trinidadrecoleta.cl/wp-content/themes/trinidadrecoleta_theme/pdf/REGLAMENTO_INTERNO_CEMENTERIO_CATOLICO.pdf. Fecha de consulta: 27 de mayo de 2017

Reglamento Interno y de arreglos de Sepulturas y Nichos, Cementerio MetropolitaNO, en http://www.cementeriometropolitano.cl/quienes-somos. Fecha de consulta: 27 de mayo de 2017

Reglamentos Internos de los Cementerios Parque del Recuerdo Américo Vespucio, Cordillera y Padre Hurtado, disponible en http://www.parquedelrecuerdo.cl/footer/ reglamento-parques. Fecha de consulta: 27 de mayo de 2017

Siete Partidas, de Alfonso X de Castilla. 